Saudi Journal of Medicine

Abbreviated Key Title: Saudi J Med ISSN 2518-3389 (Print) |ISSN 2518-3397 (Online)

\title{
Evaluation of Serum Levels of HBV-DNA Concentration and HBSAG Titers of Hepatitis B Virus-Infected Subjects at NAUTH Nnewi
}

\author{
Obiomah Chinwe Favour ${ }^{1,2^{*}}$, Amilo Grace $\mathrm{I}^{2}$, Kalu Stephen $\mathrm{O}^{1}$, Ndulue Israel $\mathrm{N}^{1}$ and Obeagu Emmanuel Ifeanyi ${ }^{3,4}$ \\ ${ }^{1}$ Department of HIV Care, Nnamdi Azikiwe University Teaching Hospital, Nnewi, Anambra State, Nigeria \\ ${ }^{2}$ Department of Medical Laboratory Science, Nnamdi Azikiwe University Nnewi Campus, Anambra State, Nigeria \\ ${ }^{3}$ Medical Laboratory Science, University Health Services, Michael Okpara University of Agriculture, Umudike, Abia State, Nigeria \\ ${ }^{4}$ Department of Medical Laboratory Science, Imo State University, Owerri, Imo State, Nigeria
}

DOI: $10.36348 /$ sjm.2020.v05i01.006 $\quad$ | Received: 04.01.2020| Accepted: 17.01 .2020 | Published: 22.01 .2020

*Corresponding author: Obiomah Chinwe Favour

\section{Abstract}

Hepatitis B is an infectious disease of great public health importance. Nigeria is one of the countries with the highest incidence of Hepatitis B Virus (HBV) infection worldwide. However, the accessibility and affordability of HBV DNA quantification (viral load) assay which is the key laboratory test for therapy initiation, and monitoring is a challenge to HBV management. The study was done to evaluate serum levels of HBV-DNA concentration and HBsAg titers of hepatitis b virus-infected subjects at NAUTH Nnewi. Cross sectional study design was used with a total of 264 subjects comprising of $88 \mathrm{HBsAg}$ seropositive treatment naïve subjects, $88 \mathrm{HBsAg}$ seropositive subjects on antiviral therapy as case subjects and 88 age-matched apparently healthy HBsAg seronegative individuals were recruited as control subjects. Hepatitis BVirus DNA assay was performed using real time PCR technique, ELISA technique was used for Hepatitis B surface antigen quantification, Hepatitis Bcore Antibody Immunoglobulin M and Hepatitis D Virus Immunoglobulin G assay. Immunochromatography was used for HBV Panel, Hepatitis C Virus assay, Human Immunodeficiency Virus testing. HBsAg quantification showed strong positive correlation with HBV DNA viral load both in treatment and nontreatment groups $(\mathrm{r}=0.673 ; \mathrm{p}<0.001)$. The non-treatment group has higher viral load $(\mathrm{M}=805.50 \mathrm{IU} / \mathrm{ml}) \mathrm{compared}$ with treatment group $(\mathrm{M}=65.50 \mathrm{IU} / \mathrm{ml})(\mathrm{p}<0.001)$.

Keywords: HBV-DNA concentration, HBsAg Titers, hepatitis B virus subjects.

Copyright @ 2020: This is an open-access article distributed under the terms of the Creative Commons Attribution license which permits unrestricted use, distribution, and reproduction in any medium for non-commercial use (NonCommercial, or CC-BY-NC) provided the original author and source are credited.

\section{INTRODUCTION}

Hepatitis $\mathrm{B}$ is an infectious disease of great public health importance caused by hepatitis B virus (HBV). It is an enveloped DNA virus that infects the liver and causes hepatocellular necrosis and inflammation [1]. This virus belongs to the family hepadnaviridae and genius orthohepatodnavirus and it is the only hepadnavirus that causes infection in humans [2]. Hepatitis B virus is one of several viruses known to cause viral hepatitis and continues to be the major cause of viral hepatitis in the developing and underdeveloped world. In addition to causing chronic liver disease and cirrhosis, it has a formidable track record of being linked to primary hepatocellular carcinoma. It is estimated that $\mathrm{HBV}$ and $\mathrm{HCV}$ is the root cause of about $80 \%$ of all hepatocellular carcinomas (HCC) by promoting cirrhosis which significantly reduced the life expectancy of the infected patients [3].
About 257 million people are chronically infected annually and about 2 in 3 people with Hepatitis B do not know they are infected [4]. Recent statistics indicate that not less than 23 million Nigerians are estimated to be infected with the HBV, making Nigeria one of the countries with the highest incidence of HBV infection in the world [5]. A national study done in Nigeria in 2016 shows a prevalence rate of 12.4 percent [6]. This worldwide burden of hepatitis B mandates accurate and timely diagnosis of patients infected with $\mathrm{HBV}$ and the use of treatment strategies derived from evidence-based guidelines. Most hepatitis B patients are asymptomatic in the early stage as specific clinical symptoms often occur at advanced disease stages, which are usually irreversible. Hence, the prognosis of the infection to liver disease is very crucial. The presence of derangement in specific laboratory analytes at the early stage of infection may signal a risk of fibrosis, cirrhosis and ultimately HCC. 
The diagnosis of HBV is not only imperative but also complex because of different viral antigens, which bring about varying serological profiles in different stages of the disease [7]. The ability of HBV to induce chronic hepatic inflammation gives rise to these intricate serological profiles. Serological markers are used routinely as diagnostic and prognostic indicators of acute and chronic HBV infection [8].

Among all the several clinical diagnostic tests which have been developed for the detection of HBV infections, the serum HBV DNA level is a key factor affecting the initiation of antiviral therapy and evaluation of its efficacy [9]. Evaluation of the relationship between the serum HBV DNA levels and hepatic pathology is a current hotspot in the diagnosis and treatment of CHB [10]. Quantification of the HBsAg levels has received renewed attention because of its diagnostic potential in predicting the response to antiviral treatment and identifying the infection status of an individual [11]. Determination of the circulating levels of HBsAg could provide crucial information that could complement the measurement of HBV DNA. Studies of HBV infections conducted under various clinical settings have suggested that serum $\mathrm{HBsAg}$ could be used as a combinative or substitutive marker of HBV DNA levels [12].

Hepatitis B Virus DNA quantification has been in use for diagnosis and monitoring of patients who are being treated for chronic hepatitis B (CHB). This diagnostic method is molecular-based and expensive; thus, less complex and cheaper laboratory tests as surrogate diagnostic markers might simplify hepatitis B management [3]. Quantification of hepatitis B surface antigen (HBsAg) by automated chemiluminescent micro-particle immunoassay has been proposed to be a surrogate marker [13].

The study was done to evaluate serum levels of HBV-DNA concentration and HBsAg titers of hepatitis b virus-infected subjects at NAUTH Nnewi.

\section{MATERIALS AND METHODS Study Area}

The study was carried out at the Gastroenterology unit of Nnamdi Azikiwe University Teaching Hospital (NAUTH).

\footnotetext{
Study Design

Cross sectional study design was used in the study. A total of 264 subjects were recruited which comprised of $88 \mathrm{HBsAg}$ seropositive treatment naïve subjects, 88 HBsAg seropositive subjects on antiviral therapy (Tenofovir $300 \mathrm{mg}$ daily/Entecavir $0.5 \mathrm{mg}$ daily or Pegylated interferons $180 \mu \mathrm{g}$ weekly) as case subjects and 88 age-matched apparently healthy $\mathrm{HBsAg}$ seronegative individuals were recruited as control subjects.
}

\section{Sample Size Determination}

Power analysis for a one-way ANOVA with three groups was conducted in $\mathrm{G}$ Power to determine a sufficient sample size using an alpha of 0.05 , a power of 0.96 , and a medium effect $\operatorname{size}(\mathrm{f}=0.25)$. Based on the aforementioned assumptions, the total sample size is 264, with 88 subjects per group [14].

\section{Sampling Technique}

Purposive sampling technique was employed in selecting the participants based on the inclusion criteria. Patients that gave their consent who also met the selection criteria were recruited as they come to the clinic until the sample size was completed.

\section{Sample Collection}

After obtaining informed consent, $10 \mathrm{ml}$ of venous blood was collected from the fore arm of each subjects using a disposable syringe; $7 \mathrm{ml}$ was dispensed to a sterile $\mathrm{K}_{2}$-EDTA vacutainer $(1.2 \mathrm{mg} / \mathrm{ml}$ concentration) for hepatitis B DNA Viral load, retroviral screening (RVS) and anti $\mathrm{HCV}$ screening while $3 \mathrm{ml}$ was added to a sterile plain container for HBsAg quantitation, HDV IgG assay. The plasma and serum samples were separated into sterile plastic containers and preserved at $-86^{\circ} \mathrm{C}$.

\section{Ethical Consideration \\ Ethical Approval}

Ethical approval was sought and obtained from the Ethics Committee of Nnamdi Azikiwe University Teaching Hospital Nnewi before the commencement of this study (Reference: NAUTH/ CS /66 /VOL.10/187/2017/096).

\section{Inclusion Criteria}

Participants included in this study were hepatitis B seropositive subjects attending Gastroenterology Clinic of NAUTH, Nnewi and apparently healthy $\mathrm{HBsAg}$ seronegative individuals (NAUTH staff, students and others) who gave their consent.

\section{Exclusion Criteria}

Those patients who were co-infected with $\mathrm{HIV}, \mathrm{HDV}$ and $\mathrm{HCV}$ including $\mathrm{HBsAg}$ seronegative subjects who have received $\mathrm{HBV}$ vaccination were excluded from the study.

\section{Laboratory Diagnosis \\ HBV DNA Viral Load using CobasAmpliprep/ Taqman Real Time PCR Technique (Roche Molecular System Inc, USAas described by Iregbu and Nwajiobi-Princewill [1]}

\section{Procedure}

The frozen plasma was placed at room temperature until completely thawed before use. The High Positive, Low Positive and Negative controls were removed from $2-8^{\circ} \mathrm{C}$ storage and brought to room 
temperature before use. All reagent cassettes were removed from $2-8^{\circ} \mathrm{C}$ storage and loaded immediately onto the COBAS AmpliPrep Instrument and allowed to equilibrate to ambient temperature on the instrument for at least 30 minutes before the first specimen was processed. The appropriate number of reagent cassette racks, sample racks with Input S-tubes, SPU racks, Ktip racks, K-tube racks and $\mathrm{K}$-carriers on K-carrier racks was loaded onto the respective rack positions of the COBAS AmpliPrep Instrument. Sample rack was prepared by attaching a barcode label clip to each sample rack position where a specimen (S-tube) was to be placed. The specific barcode label clips for the controls were attached to each sample rack position where the controls (S-tube) were to be placed. One Input S-tube was placed into each position containing a barcode label clip.

The Amplilink software was used to create specimen orders for each specimen and control in the Orders window Sample folder and HBV test definition file was selected and saved. The specimen and controls were vortexed for 5 seconds and $650 \mu \mathrm{L}$ added to the Stubes. The tubes were then inserted in the sample rack and loaded to the Ampliprep. The Amplilink software was used to start the COBAS Ampliprep. At the completion of the COBAS TaqMan Analyzer run, the Results Report was validated and printed.

\section{HBsAg Quantification by ELISA Technique (Fortress Diagnostics Limited United Kingdom as described by Bhatnagar et al., [15]}

\section{Procedure}

The wells were marked and $20 \mu$ l of Specimen Diluents were added into each well except the blank. Then $100 \mu$ of Positive control, Negative control and Specimen were added into their respective wells except the blank. The plate was covered with plate cover and incubated for $60 \mathrm{mins}$ at $37^{\circ} \mathrm{C}$. At the end of the incubation, the plate cover was removed and discarded, $50 \mu 1$ HRP-Conjugate were added into each well except the blank and mixed by tapping the plate gently. The plate was then covered and incubated at $37^{\circ} \mathrm{C}$. At the end of the second incubation, each well was washed times with diluted buffer allowing microwells to soak for 30-60 secs each time. After the final washing cycle, the plate was turned down onto blotting paper and tapped to remove any remnant. After the washing, $50 \mu \mathrm{l}$ of Chromogen A and 50 $\mu$ l of Chromogen B solutions were added into each well including the blank incubated in the dark at $37^{\circ} \mathrm{C}$ for 30 mins. After the incubation, $50 \mu \mathrm{l}$ of stop solution was added into each well using multichannel pipette and mixed gently. The blank was then used to calibrate the plate reader and the absorbance was read at $450 \mathrm{~nm}$.
Anti HBcAb IgM quantitation by ELISA (Diagnostics Automation Inc. Woodland Hills, California as described by Kesslar et al., [16] Procedure

All reagents and samples were brought to room temperature before use. The number of wells needed for the assay were removed from storage and the remaining were kept back at $4^{\circ} \mathrm{C}$. Three wells were marked as negative controls, two wells, positive controls and one blank. Then, $100 \mu$ l of samples and controls were added into their respective wells and Blankwell was set without any solution. Adhesive strips were used to cover the wells and incubated for 30 minutes at $37^{\circ} \mathrm{C}$. At the end of the incubation, the strips were removed, and each well was washed five times with diluted buffer allowing the microwells to soak for 60 secs at each washing. After the final washing cycle, the plate was turned down onto a blotting paper and tapped to remove any remaining liquid. Then, $100 \mu$ of HRP-Conjugate reagent was added into each well except the blank covered and incubated for 30mins at $37^{\circ} \mathrm{C}$. The plate cover was then removed and the aspiration/wash process was repeated for five times, $50 \mu \mathrm{l}$ each of Substrate A and B were added to each well, incubated for $15 \mathrm{mins}$ at $37^{\circ} \mathrm{C}$ avoiding light. Multichannel pipette was used to add $50 \mu$ l of stop solution into each well and mixed gently. The blank well was used to calibrate the plate reader and the absorbance was read at $450 \mathrm{~nm}$. The cut-off for each batch was calculated using the mean optical densities of the negative control in accordance with the manufacturer's instruction. This cut-off value was then used to calculate the activity index for each sample by dividing the mean OD of each sample with the cut-off value. Samples with the activity index values higher or equal to those of positive control were considered positive, while those with values below were reported as negative (Index value > 1.10 was reported as positive).

\section{HDV IgG ELISA by Diagnostics Automation Inc. Woodland Hills, California (as described by Lai, 1995) [17]}

\section{Procedure}

The reagents and samples were brought to room temperature and votexed before use. The number of wells needed for the assay was removed from storage. Then $100 \mu$ lof specimen diluents were added to into each well except the blank. Three wells were marked as negative controls, two wells, positive controls and one blank. Also, $10 \mu$ l of positive, negative controls and samples were added into their respective wells except the Blankwell covered and incubated for 30 minutes at $37^{\circ} \mathrm{C}$. At the end of the incubation, the strips were removed, and each well was washed five times with diluted buffer allowing the microwells to soak for $60 \mathrm{secs}$ at each washing. After the final washing cycle, the plate was turned down onto a blotting paper and tapped to remove any remaining 
liquid, $100 \mu \mathrm{l}$ of HRP-Conjugate reagent was then added into each well except the blank covered and incubated for 30 mins at $37^{\circ} \mathrm{C}$. The plate cover was then removed, and the aspiration/wash process was repeated for five times, $50 \mu \mathrm{l}$ of Chromogen A and Chromogen B were added to each well, incubated for $15 \mathrm{mins}$ at $37^{\circ} \mathrm{C}$ in the dark. Multichannel pipette was used to add $50 \mu$ l of stop solution into each well and mixed gently. Intensive yellow colour developed in Positive control and HDV IgG positive sample wells. The blank well was used to calibrate the plate reader and the absorbance was read at $450 \mathrm{~nm}$.

\section{Anti-Hepatitis C Virus (HCV) Serological Assay (Chembio Diagnostic Systems, Inc. Medford, Newyork as described by CDC, 2003 [18] Procedure}

The test kit was brought to room temperature, removed from the foil and placed on a flat surface. It was labeled with the specimen's identification number, and approximately $50 \mu \mathrm{l}$ of the serum sample was applied onto the sample pad. The test was allowed to run for 15 minutes after which the result was read.

\section{Human Immunodefiency Virus (HIV) Screening by Serial Algorithm \\ Determine HIV 1/2 Assay (Abbort Rapid Diagnostics CA, USA as described by Delaney and Branson, 2011 [19]}

\section{Test Procedure}

The protective foil was removed, and the test device was kept on a flat surface. The device was labeled with the specimen's identification number and $50 \mu 1$ of the serum sample was applied to the sample pad. The result was read after 15 minutes.

Unigold HIV 1/2 Rapid Test (Trinity Biotech PLC, Ireland as described by CDC, 2001 [20]

\section{Procedure}

The test device was removed from the protective wrapper and kept on a flat surface. On the sample port, $60 \mu 1$ of serum sample was added also, two drops of wash buffer reagent. Result was read after 10 minutes.

Chembio Stat-Pak HIV 1/2 Assay (Chembio Diagnostic Systems, Inc. Medford, Newyork as described by Kenealy et al., 1987 [21]

\section{Test Procedure}

The test kit was removed from its pouch and placed on a flat surface. The test device was labeled with specimen's identification number. The $5 \mu$ l sample loop was touched on the specimen allowing the opening of the loop to be filled. The sample loop was then held vertically to touch the centre of the SAMPLE (S) well of the device to dispense approximately $5 \mu \mathrm{l}$ of sample onto the sample pad. The Running Buffer bottle was held vertically and three drops (approximately 105 $\mu 1$ ) of the Buffer was added slowly. The test result was read after 10 minutes of adding the Running Buffer.

\section{STATISTICAL ANALYSIS}

Data obtained were analyzed using Statistical Package for Social Sciences (SPSS) version 20) software. Data were expressed as mean \pm SD and median. The significance of differences in mean values among groups were analyzed using one-way Anova for normally distributed variables, while Kruskall Wallis was used to analyze the significant differences in median values among different groups for variables not normally distributed. Mann-Whitney was also used to analyse significant differences between groups. Spearman's correlation coefficient was used to assess the levels of relationship between two variables. Regression analysis and receiver Operators curve were also used appropriately. The level of significance was considered at $\mathrm{p}<0.05$.

\section{RESULTS}

Median serum levels of HBV-DNA concentration and HBsAg Titers of the hepatitis B subjects

Table-1 shows that the median serum HBV DNA level observed in the whole cohort $(n=176)$ was $422.50 \mathrm{IU} / \mathrm{mL}$, whereas the median serum HBsAg titer was $1350.50 \mathrm{IU} / \mathrm{mL}$. There was no significant difference in the median HBV DNA level in the male group compared with the female group patients; 475 $\mathrm{IU} / \mathrm{mL}$ ) versus $337 \mathrm{IU} / \mathrm{mL}) ; P=0.523$. A similar pattern was observed for the HBsAg titer whose median values did not show significant gender differences.

Correlation between serum HBsAg titers and HBVDNAin: (a) the whole hepatitis B patient cohort (b) drug treatment group (c) the treatment naïve group Pearson's linear regression analysis indicated a significant positive correlation between $\mathrm{HBsAg}$ and HBV DNA among all patients at $r=0.627, P<0.001$ as shown in Figure-1a. Similarly, there were significantly positive correlations between HBsAg and HBV DNA for both the treatment and non treatment groups, (Fig1b, $r=0.565, P<0.001$ and Fig-1c, $r=0.673, P<$ $0.001)$

Table-1: Median serum levels of HBV-DNA concentration and HBsAg Titers of the hepatitis B subjects

\begin{tabular}{|l|l|l|l|l|}
\hline Variable & Whole Cohort $(\mathbf{n}=\mathbf{1 7 6})$ & Males $(\mathbf{n}=\mathbf{1 0 0})$ & Females $(\mathbf{n}=\mathbf{7 6})$ & P Value \\
\hline HBVDNA $(\mathrm{IU} / \mathrm{mL})$ & 422.50 & 475.0 & 337.0 & 0.523 \\
\hline HbsAg $(\mathrm{IU} / \mathrm{mL})$ & 1350.50 & 1355.0 & 1343.50 & 0.239 \\
\hline
\end{tabular}

Key: HBV DNA = Hepatitis B Viral DNA Quantification, HBsAg = Hepatitis B surface antigen quantification. 


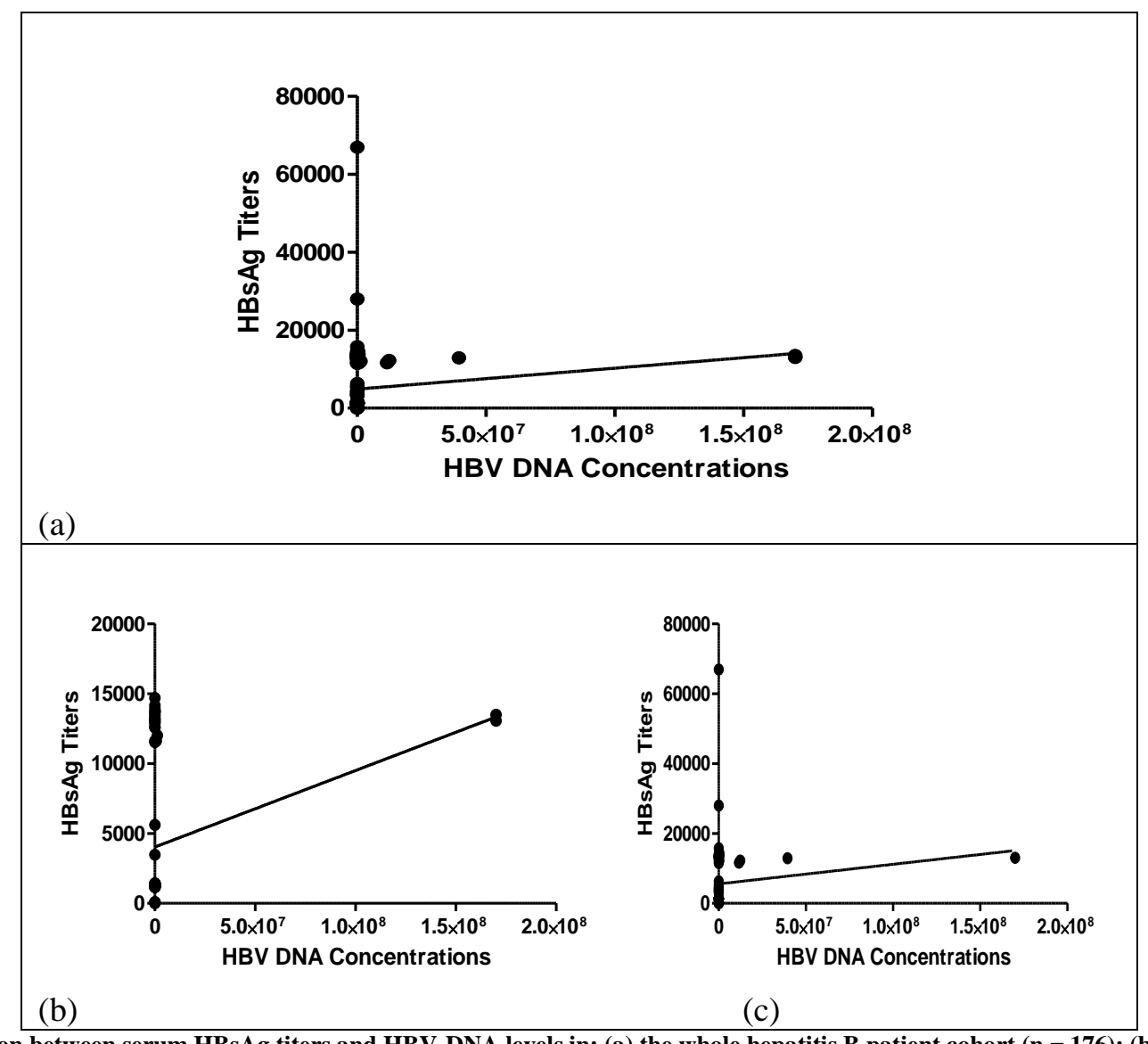

Fig-1: Correlation between serum HBsAg titers and HBV-DNA levels in: (a) the whole hepatitis B patient cohort (n = 176); (b) drug treatment group $(n=88)$ (c) the treatment naïve group $(n=88)$

\section{DISCUSSION}

Quantification of HBsAg indirectly reflects the number of infected hepatocytes and is known to change over the natural course of chronic HBV infection [22]. Also, during antiviral therapy, it could be used to differentiate true inactive carriers from patients in remission who are likely to progress to cirrhosis [23]. The HBsAg quantification in this study, showed a strong positive correlation with HBV viral load both in treatment and non treatment groups. Kim et al., 2011 [24] also reported a high significant correlation $(\mathrm{r}=0.657, \mathrm{P}<0.001)$. On the contrary, Ganji et al., [25] reported negative correlation between $\mathrm{HBsAg}$ and $\mathrm{HBV}$ viral load among chronic HBV infected individuals. The variations could be due to differences in disease stage, $\mathrm{HBeAg}$ status and HBV genotypes involved.

The above finding also agrees with Kim et al., [24] and supports the fact that hepatitis B surface antigen (HBsAg) is an important diagnostic marker, generally detectable in patients with acute and chronic infection; positive testing indicates high $\mathrm{HBV}$ replication in the liver, elevated blood HBV titers and greater infectivity to others. Level of HBsAg correlates with covalently closed circular DNA (cccDNA) level in the liver and reflects the amount of cccDNA inside hepatocytes. Furthermore, it correlates with the transcriptional activity of cccDNA and is considered a surrogate marker of infected cells. Although this study demonstrates a relationship between serum $\mathrm{HBsAg}$ titers and HBV DNA levels in the whole cohort of HBsAg positive patients and in its clinical subgroups, the area under the curve $(0.537 ; \mathrm{p}=0.002)$ showed that HBsAg quantitation indicated a very poor performance in discriminating or distinguishing between normal and abnormal viral loads in hepatitis B subjects, when compared with the serum HBV-DNA test. This suggests that HBsAg quantitation may not be an effective alternative to serum HBV-DNA quantification in hepatitis B virus infected patients. This finding is similar to the report of Mathia et al., [26]. HBVDNA, is the template for gene transcription and replication and level is the most important and most direct etiological evidence for $\mathrm{HBV}$.

The sex distribution of the subjects in this study showed that there were more males 100(57.2\%) males and $76(42.8 \%)$ females. This shows that HBV infection is more prevalent in males than females and the finding is in keeping with the findings of Yewande et al., [27] which reported males are 2.8 times more likely to get infected with HBV compared to their female counterparts [7]. This could be due to the fact that males are more prone to risk factors and behaviors sexual intercourse, injection drug use, barbing et ce tera which predispose them to $\mathrm{HBV}$ infection. Regarding 
the age distribution, highest frequency of $\mathrm{HBsAg}$ seropositivity was found among the younger age group 21-30 followed by 31-40 group for both males and females. Also another work done by Gheorghe et al., [28] gave a similar report. Considering the modes of transmission of $\mathrm{HBV}$, the high sexual activity of individuals within these age brackets might explain this. The age group $<20$ had the least frequency both among males and females (3.9 and 3.9) respectively. The >50 age group were the second to the least of the subjects (9\% females and $12 \%$ for females). This finding is in agreement with that of Yewande et al., [27]. The children $(<20)$ and the aged $(>50)$ have less exposure to risky behaviours than the middle aged (21-30, 31-40).

\section{CONCLUSION}

This study has revealed that HBsAg quantification has strong correlation with $\mathrm{HBV}$ viral load but might not be efficient in clinical practice as a predictor of serum HBV viral load due to its poor performance characteristics in identifying high positive viral load.

\section{REFERENCES}

1. Iregbu, K., \& Nwajiobi-Princewill, P. (2016). Viral load pattern among hepatitis B surface antigen-positive patients: Laboratory perspective and implications for therapy. Annals of Medical and Health Science Research. 6:95-99.

2. Fairley, C., \& Read, T. (2012). Vaccination against sexually transmitted Infections. Current Opinion in Infectious Diseases. 25(1): 66-72.

3. Crossan, C., Tsochatzis, E. A., Longworth, L. Gurusamy, K., Davidson, B., RodríguezPerálvarez, M., Mantzoukis, K., O'Brien, J., Thalassinos, E., Papastergiou, V., \& Burroughs, A. (2015). Cost-effectiveness of non-invasive methods for assessment and monitoring of liver fibrosis and cirrhosis in patients with chronic liver disease: systematic review and economic evaluation. Health Technology Assessment. 19(9):1-410.

4. CDC.(2018).WhatisViralHepatitis?Availableat:htt ps://www.cdc.gov/hepatitis/abc/index.htm(Access ed: 11 May 2018).

5. WHO.(2017). Epidemiological Update: Increasing mortality calls for action. Hepatitis B Global Report.17:1-11.

6. Olayinka, A. T., Oyemakinde, A., Balogun, M. S., Ajudua, A., Nguku, P., Aderinola, M., EgwuenuOladejo, A., Ajisegiri, S. W., Sha'aibu, S., Musa, B. O., Gidado, S., \& Nasidi, A. (2016). Seroprevalence of Hepatitis B Infection in Nigeria: A National Survey. American Journal of Tropical Medicine Hygiene. 95(4):902-907.

7. Nwokediuko, S. (2011). Chronic hepatitis B: management challenges in resource-poor countries. Hepatitis monthly Kowsar Medical Institute. 11(10):786-793.
8. Amorocho, H., Domínguez, Y., \& García, A. (2012). Serological and molecular markers for Hepatitis B virus in university students. Revista Colombia de Gastroenterologia. 27(4): 281-289.

9. 10. Demiroren, K., Kocamaz, H., \& Dogan, Y. (2015). The importance of the serum quantitative levels of hepatitis B surface antigen and hepatitis $\mathrm{B}$ e antigen in children with chronic hepatitis B. The Turkish Journal of Gastroenterology. 26(1): 36-41.

10. Cornberg, M., Wong, V. W. S., Locarnini, S., Brunetto, M., Janssen, H. L., \& Chan, H. L. Y. (2017). The role of quantitative hepatitis B surface antigen revisited. Journal of hepatology, 66(2), 398-411.

11. Li, G., Wang, J., Bao, Y., Zheng, L., Ge, K., Zhou, X., \& Chen, G. (2015). Clinical significance of serum HBsAg levels, HBsAg/HBV DNA ratio, and association with liver inflammation activity in HBeAg-positive chronic hepatitis B. Zhonghua gan zang bing za zhi= Zhonghua ganzangbing zazhi= Chinese journal of hepatology, 23(1), 4045.

12. Chan, H. L., Thompso, A., Martinot-Peignoux, M., Piratvisuth, T., Cornberg, M., Brunetto, M. R., Tillmann, H. L., Kao, J. H., Jia, J. D., Wedemeyer, H, Locarnini, S., Janssen, H. L., Marcellin P. (2011). Hepatitis B surface antigen quantification: Why and how to use it in 2011 - A core group report. Journal of Hepatology. 55(5):1121-1131.

13. Eke, A. C., Eleje, G. U., Eke, U. A., Xia, Y., \& Liu, J. (2017). Hepatitis B immunoglobulin during pregnancy for prevention of mother-to-child transmission of hepatitis B virus. Cochrane Database of Systematic Reviews. 2:CD008545.

14. Faul, F., Erdfelder, E, Buchner, A., \& Lang, A. (2013). G*Power Version 3.1.7 [computer software]. Uiversitat Kiel, Germany. Retrieved from http//www.psycho.uniduesseldorf.de/abteilungen/aap/gpower3/download -and-register. (Accessed on $20^{\text {th }}$ August, 2019).

15. Bhatnagar, P., Papas, H., Blum, D., Milich, D., \& Nitecki, M. (1982). Immune Response to Synthetic peptide Analogues of Hepatitis B Surface antigen specific for the determinant. Proceedings of National Academy of Science.79: 4400-4404.

16. Kesslar, H., Pierer, E., Dragon, H., Lackner, B., Santner, D., \& Stelzi, B. (1998). Evaluation of a New assay for HBV DNA Quantitation in Patients with Chronic Hepatitis B. Clinical Diagnosis in virology. 37-43.

17. Lai, M. C. (1995). The molecular biology of hepatitis Delta virus. Annual Review of Biochemistry. 64:259-286.

18. CDC. (2003). Guidelines for Laboratory Testing and Result Reporting of Antibody to Hepatitis C Virus. Morbidity and Mortality Weekly Report. s52: 1-16. 
19. Delaney, K. P., \& Branson, B. M. (2011). Evaluation of the performance characterisics of Rapid HIV Antibody Tests. Clinical Infectious Diseases. 52(2):257-263.

20. CDC. (2001). Revised guidelines for HIV counseling. Morbidity and Mortality Weekly Recommendations and Reports. 50:19.

21. Kenealy, W., Reed, D., \& Cybulsky, R. (1987) Analysis of human serum antibodies to human immunodeficiency virus (HIV) using recombinant ENV and GAG antigens. AIDS Research and Human Retroviruses. 3:95-105.

22. Seth, A. (2012). HBV Quantification in Clinical Practice. Journal of Clinical Exp Hepatology. 2(1):75-80.

23. Martinot-Peignoux, M., Lapalus, M., Asselah, T., \& Marcellin, P. (2013). The role of HBsAg quantification for monitoring natural history and treatment outcome. Liver Internatiional. 125-132.

24. Kim, B. K., Kim, D. Y., Park, J. Y., Ahn, S. H., Chon, C. Y., Kim, J. K., Paik, Y. H., Lee, K. S., Park, Y. N., \& Han, K. H. (2010) .Validation of FIB-4 and comparison with other simple noninvasive indices for predicting liver fibrosis and cirrhosis in hepatitis B virus-infected patients. Liver International. 30(4): 546-553.

25. Ganji, A., Esmaeilzadeh, A., Ghafarzadegan, K., Helalat, H., Rafatpanah, H., \& Mokhtarifar, A. (2011) Correlation between HBsAg quantitative assay results and HBV DNA levels in chronic HBV. Hepatitis Monthly. 11(5): 342-345.

26. Mathia, F., Ngayo, M., Karanja, S., Kalebi, A., \& Lihana, R. (2017). Correlation of Quantitative Assay of HBsAg and Hepatitis B Virus DNA Levels among Chronic HBV Patients Attending Pathologist Lancet Laboratory in Nairobi, Kenya. Archives of Clinical Infectious Diseases. 12(4):13306.

27. Nejo, Y., Faneye, A. O., Olusola, B., Bakarey, S., Olayinka, A., Motayo, B., \& PERVI Study Group. (2018). Hepatitis B virus infection among sexually active individuals in Nigeria: a cross-sectional study. The Pan African medical journal, 30:155.

28. Gheorghe, L., Csiki, I., Iacob, S., \& Gheorge, C. (2013). The Prevalence and Riak Factors of Hepatitis B Virus Infection in an adult population in Romania: A nationwide Survey. European Journal of Gastroenterology and Hepatology. 25(1):56-64. 